\title{
Dynamic Energy Budget provides mechanistic derived quantities to implement the ecosystem based management approach
}

Mangano, Maria; Giacoletti, Anotnio; Sara, Gianluca

\section{Journal of Sea Research}

DOI:

10.1016/j.seares.2018.05.009

Published: 01/01/2019

Peer reviewed version

Cyswllt i'r cyhoeddiad / Link to publication

Dyfyniad o'r fersiwn a gyhoeddwyd / Citation for published version (APA):

Mangano, M., Giacoletti, A., \& Sara, G. (2019). Dynamic Energy Budget provides mechanistic derived quantities to implement the ecosystem based management approach. Journal of Sea Research, 143, 272-279. https://doi.org/10.1016/j.seares.2018.05.009

\footnotetext{
Hawliau Cyffredinol / General rights

Copyright and moral rights for the publications made accessible in the public portal are retained by the authors and/or other copyright owners and it is a condition of accessing publications that users recognise and abide by the legal requirements associated with these rights.

- Users may download and print one copy of any publication from the public portal for the purpose of private study or research.

- You may not further distribute the material or use it for any profit-making activity or commercial gain

- You may freely distribute the URL identifying the publication in the public portal?
}

Take down policy

If you believe that this document breaches copyright please contact us providing details, and we will remove access to the work immediately and investigate your claim. 
Dynamic Energy Budget provides mechanistic derived quantities to implement the ecosystem based management approach

M. Cristina Manganoa,b , Antonio Giacolettia , Gianluca Saràa, [? aDepartment of Earth and Marine Science, Laboratory of Ecology, University of Palermo, Viale delle Scienze Ed. 16, 90128 Palermo, Italy b Fisheries \& Conservation Science Group, School of Ocean Sciences, 328 Westbury Mount, Bangor University, Menai Bridge, Anglesey LL59 5AB

ABSTRACT The on-going climate change threats are rapidly growing at both global and local scales, affecting ecosystems, societies and economies by altering natural distribution and productivity of key commercial species. Although the ecosystem based management (EBM) focuses on ecosystem equilibria, to provide realistic management measures for important activities at sea such as fisheries and aquaculture, there is a need of quantities; mechanistic approaches are suggested as reliable solutions. Here, a Dynamic Energetic Budget (DEB) application studies the link between environmental change (temperature forecasted increasing scenario in a context of COP 21 [Paris climate conference Agreement] and food density increase) and life-history traits of some Mediterranean fishery and aquaculture target species (Engraulis encrasicolus, Dicentrarchus labrax, Mytilus galloprovincialis, Crassostrea gigas). A sensitivity analysis was applied to simulate the effects of future environmental change on the time needed to reach the commercial size and the length at first maturity. We also explored the efficiency of Integrated Multitrophic Aquaculture (IMTA) as a potential management solution in a context of an adaptive EBM. The worst scenario of rising temperatures $\left(+2^{\circ} \mathrm{C}\right)$ seems to reduce the time needed to reach the commercial size in most species and IMTA potentiates the thermal effect on it. A spatial contextualisation of model outcomes allowed disentangling potential conflicts among human activities at sea. The DEB based life history traits approach can provides quantities to inform the management of marine activities at local scale additionally allowing translating complex results into useful figurative representations for stakeholders.

\section{Introduction}

Climate change represents an ongoing and rapidly growing threat at both global and local scale equally affecting the environment, societies and economies by forcing shifts in the distributional range and productivity of key commercial species (Lam et al., 2016). The magnitude of these effects on marine species (both in the wild and captive conditions) and their replies (e.g. increase or decline of abundance; Pecl et al., 2017) can vary and the possible changes can depend on: i) species lifehistories traits, ii) local environmental conditions and iii) contextual presence of more than one anthropogenic related stressor (Gunderson et al., 2016; Pecl et al., 2017; Sarà et al., 2018a, 2018b, 2018c). The effect of increasing temperature pushes species distribution shifts at large scales, such as the poleward shift, which seems concurrent across the current literature (Poloczanska et al., 2013; Mieszkowska et al., 2014; Rutterford et al., 2015; Sarà et al., 2018b). What is still poorly recognized and understood is how the effect of multiple drivers of environmental change vary in space and time at local scale. Additionally and contrary to what happened so far, the future management of socioeconomic important activities at sea, such as fishery and aquaculture, as well as the corresponding systems of governance, should be informed by observations and predictions made at local scale. Only a more adaptive management that integrates approaches that involve the full array of interactions within an ecosystem, including humans, rather than considering single issues in isolation, starting from an appropriate knowledge of species biological traits, will allow the translation of the effects of environmental change into realistic management measures (Carpenter and Folke, 2006). Thus, strategies of dynamic adaptation should be designed taking into account new more ongoing favourable environmental conditions affecting the optimisation of the species' 
biological traits (Sarà et al., 2018a, 2018b, 2018c) to avoid unrealistic or inapplicable management measure. Oftentimes, this leads to measures that generate conflicts in between the different anthropogenic activities that foster tension among coastal stakeholders (Baudron and Fernandes, 2015; sensu Sarà et al., 2018a).

The Dynamic Energy Budget Theory (Kooijman, 2010) feeding the functional-based approach (Schoener, 1986; Kearney and Porter, 2009; Kooijman, 2010; Sarà et al., 2014, 2018c) may represents an effective and powerful mechanistic tool in providing those kinds of quantities to inform effective and flexible fisheries and aquaculture management plans. Spatially contextualised quantities based on functional traits of fished and cultivated species (e.g. Sarà et al., 2018a) can help us in disentangling the effects of increasing temperature due to climate change. Such kind of information can preserve and reinstate the socioeconomic integrity of marine regions in shifting, dynamic and changing ecosystems (UNEP/MAP, 2016).

Here, we introduce a comprehensive approach that integrates quantities generated by a mechanistic DEB based application, with the aim to operationalize, inform and support a more adaptive management of marine resources and the related development (e.g. fisheries ad aquaculture). Our framework involves a spatially-explicit module where, by mapping our outcome, we were able to contextualise potential management issues. In this regards, Sicily, due to the crossborder central position in the Mediterranean Sea, coastal socio-economies based on sea-related products (e.g. seafood, oil and gas extraction) and peculiar physiography and oceanography, can represent an ideal case study area to test the effectiveness of integrated approaches and to explore possible benefits coming from a quantitative mechanistic analysis based on species traits (Mangano and Sarà, 2017; Mangano et al. 2017a, 2017b; Capodici et al., 2018). In doing so, we identified and quantified the spatio-temporal shifts under climate change in terms of time to reach both the commercial size for three selected aquaculture model species (Mytilus galloprovincialis, Crassostrea gigas, Dicentrarchus labrax) and the length at fist maturity for the fishery model species, Engraulis encrasicolous (hereafter TIME). All these species are common and highly valuable in the Mediterranean fisheries and aquaculture and are among the most consumed species in the Basin. We used the power of the functional-based approach to generate at regional level the kind of site-specific mechanistic predictions of species shifts resulting from climate change (in terms of increasing temperature from 0.5 to $2.0^{\circ} \mathrm{C}$ in respect of the current worst scenario increasing temperature - sensu COP 21 Paris climate conference Agreement; Hulme, 2016a, 2016b). In the specific case of two out three farmed bivalves (M. galloprovincialis and $\mathrm{C}$. gigas) we crossed the thermal outcomes with another potential source of variation such as the trophic enrichment (in terms of chlorophyll-a increase), simulating the presence of an Integrated MultiTrophic Aquaculture (IMTA; Sarà et al., 2012) when more species belonging to different trophic levels are cultivated together (Sarà et al., 2012; Sarà et al., 2018a). Thus, we performed an analysis crossing both temperature increase (from current up to $+2{ }^{\circ} \mathrm{C}$ ) and trophic condition scenarios (normo-trophic conditions vs. IMTA trophic enrichment conditions).

Quantities produced by our approach were mapped allowing to spatially visualize a quantitative informational baseline of climate effects on our target species. These can be used in helping scientists to inform policy makers and stakeholders with the final aim to produce more tailored management strategies and plans based on local scale outcomes.

\section{Materials and methods}

The DEB model represents the "quantitative from scratch" framework which mechanistically investigates the fluxes of energy that one organism activates in order to optimize fitness during the life span (Marquet et al., 2014; Kearney et al., 2015). The mechanistic properties rely on energy and 
matter flows from habitat through organisms. Flows of energy and matter (and time) through habitats and organisms are subjected to conservation laws (Charnov and Krebs, 1974) and, consequently, they are traceable (and "budgetable" accountable) processes. We can use these principles to mechanistically predict the functioning of each species and thereby the magnitude and variability of life-histories traits (Loreau, 2010; Kearney, 2012; Pethybridge et al., 2013). The standard DEB model (Kooijman, 2010; Kearney, 2012) incorporates whole-organism bioenergetics, allowing the connection between the individual behaviours to population growth via the description of how energy and mass are managed by organisms and how metabolic tradeoffs are involved in response to local environmental change. The mechanistic nature of the standard DEB model allows that the bioenergetics features of any organism may be related to environmental conditions, so that growth rate and the ultimate fitness can be predicted. This is only feasible if the organismal body temperature and food density available are known, as for our four studied target species and when all DEB parameters of that species have been estimated (Pethybridge et al., 2013). Here we selected two fishes, the European anchovy, Engrauils encrasicolus and the European seabass, Dicentrarchus labrax, and two bivalve molluscs, the Japanese oyster, Crassostrea gigas and the Mediterranean Blue mussel, Mytilus galloprovincialis (Fig. 1). Metabolic rates of these ectotherms such as all living organisms depend on body temperature and the available food density of the environment where organisms live. DEB describes the dynamics of these processes Fig. 1. Conceptual framework showing the simulated scenario of "temperature" increase (from current scenarios, years 2011-2014 to $+2{ }^{\circ} \mathrm{C}$, step $0.5^{\circ} \mathrm{C}$ ) and "food" increase (from a current "normotrophic" condition, 2011-2014 CHLa, to "eutrophic" condition $+2 \mu \mathrm{gl}-1)$ ). Variation of the commercial size, proxy of the duration of the grow-out production phase, have been modelled along a temperature and food increasing scenarios for the two bivalve aquaculture target species (Mytilus galloprovincialis and Crassostrea gigas) in order to text the Integrated Multi-Trophic Aquaculture, IMTA, effects as a potential management solution in a context of an adaptive ecosystem based approach. Variations of the commercial size of the farmed fish, Dicentrarchus labrax, and length at first maturity on the fisheries target species, Engraulis encrasicolus, have been modelled along a temperature-increasing scenario only. Notes: the $+2{ }^{\circ} \mathrm{C}$ temperature increase value reflects the foreseen worst temperature increasing scenario in COP21 (Paris climate conference Agreement, 2015); the $+2 \mu \mathrm{gl}-1$ food increase value (Chlorophyll-a, $\mathrm{CHL}-\mathrm{a})$ reflects an eutrophic condition simulating the trophic enrichment of a typical IMTA, condition. Data on the farming or fisheries methods, selected sizes, vulnerability, price and spawning have been reported to better characterise the selected target species (FAO CASIP, 2004http://www.fao.org/fishery/culturedspecies; https:// www.fishbase.org/; http://www.sealifebase.org/). M.C. Mangano et al. Journal of Sea Research xxx (xxxx) xxx-xxx 2 and the possibility of modelling the effects of body temperature and food density assumes an important role to predict where, when and with what magnitude species' persistence evolves over time (Montalto et al., 2014) with potential repercussions on biodiversity and local economies. The amount of energy from food available to biological processes is regulated, in the DEB theory, by Holling's functional responses (Holling, 1959). Once food is ingested, the amount of energy from food flows through the organism at some extent depending on physiological rates. Body temperature represents an important constraint in the DEB theory especially in ectotherms in which it approximates that of the mean temperature (e.g. seawater as in fish). The effect of temperature on metabolism follows the Arrhenius relationship (1889) (Kooijman, 2010). Arrhenius temperature and the lower and upper boundaries of the body temperature tolerance range can be extrapolated from literature data or estimated by a direct calculation of physiological rates at different temperatures (Pethybridge et al., 2013; Sarà et al., 2013a, 2013b). The DEB model allows us to quantify some of the most important life history traits (Sarà et al., 2011, 2014). For the purpose of this study, we extrapolated and presented the duration of the grow-out phase as expressed in terms 
of days (TIME), needed to reach the minimum "commercial size" for the three aquaculture target species and the minimum "length at first maturity" for the fisheries species. These size were gathered from literature (FAO CASIP, 2004; http:// www.fao.org/fishery/culturedspecies; https://www.fishbase.org/; http://www.sealifebase.org/). In Table 1 and Fig. 1, we both reported DEB parameters for all species and a graphical description of the applied approach on the model target species.

\subsection{Environmental variables to run DEB models}

To study the potential overlap among activities at sea, aquaculture and fisheries, we spatially contextualised our analysis in the central Mediterranean Sea, around Sicily. Sicilian coasts provide an ideal model area to test the power of this mechanistic approach as there are many conflicts at sea to be solved and local economies strongly rely on fisheries and aquaculture products. Thus, we downloaded 4-year datasets (2011-2014) from the Environmental Marine Information System (EMIS) maintained at the European Joint Research Centre website (http://emis.jrc.ec.europa.eu/) and MyOcean (http://www.myocean. eu) of, respectively, daily chlorophyll-a (CHL-a), weekly Net Primary Production (NPP) and daily Sea Surface Temperature (current SST). These datasets were used to feed DEB models of present 4 target species under current conditions (2011-2014). Data have been downloaded with a spatial resolution of $0.11^{\circ}$ to obtain 68 coastal pixels covering about $850 \mathrm{~km}$ of the Sicilian coastline. SST and CHL-a were obtained for all 68 pixels and CHL-a was used as a proxy of available food to bivalve target species as commonly carried out in the current literature and in several companion studies (e.g. Sarà et al., 2011, 2012, 2013b, 2014, 2018b). Instead, for the European anchovy which was the only wild fisheries species, we extrapolated a spatially continuous dataset of food density throughout the study area and across time (Strömberg et al., 2009). This method transforms the local Net Primary Production into wet mass of zooplankton ( $\mathrm{mg} \mathrm{m}-3$ ) starting from values of Carbon per Unit Volume expressed as grams of Carbon per cubic metre and after having converted it into the wet mass of zooplankton by the coefficient of conversion provided by Cushing et al. (1958). Food for anchovy was obtained only for 45 pixels due to the lack of consistent Net Primary Production data in 23 pixels out 68. For the only intensive cultivated captive species (seabass; i.e. not relying on natural food under wild conditions; Sarà et al., 2018a), the effect of food was expressed through calibrating the functional response using growth and environmental data coming from Sicilian farms (Sarà et al., 2018c). Thus, we adjusted the half-saturation coefficient (which is a measure of how much organism are able to adapt to local food conditions) to fit the observed fish length reached in Sicilian farms.

To simulate the future increasing temperature scenarios forecasted by COP 21 (Hulme, 2016a, 2016b), we performed a simulation study (hereafter sensitivity analysis). Thus we ran DEB models pixel by pixel and increasing the current temperature from $0.5^{\circ} \mathrm{C}$ to $2.0^{\circ} \mathrm{C}\left(0.5^{\circ}\right.$ step $)$, we obtained 4 increasing temperature DEB scenarios (current $+0.5^{\circ} \mathrm{C},+1.0^{\circ} \mathrm{C},+1.5^{\circ} \mathrm{C},+2.0^{\circ} \mathrm{C}$; Fig. 1). The procedure was stopped at $+2.0^{\circ} \mathrm{C}$ which represents the worst COP 21 scenario expected in the coming years (Hulme, 2016a, 2016b). We decided to apply this type of procedure as it is defined more reliable than using IPCC (AR4 or AR5; Montalto et al., 2016) simulations from current up to the year 2050-2075 based on the Representative Concentration Pathways, RCPs (Moss et al., 2010; Cheung et al., 2017).

One objective of this study was to explore the efficiency of IMTA as a potential management solution in a context of an adaptive ecosystem based approach. Thus, we ran pixel by pixel models for bivalves both under current "normotrophic" conditions - as expressed by current CHL-a data (2011-2014) - and under "eutrophic" conditions as expressed by a CHL-a increment of 2.0 $\mu \mathrm{g} \mathrm{I-1}$ 
(according to Sarà et al., 2012 observations of the fish culture trophic aided-enrichment on Crassotrea gigas and Mytilus galloprovincialis life-histories traits; Gulf of Castellamamre, Sicily).

In total, we ran 1925 simulations and data have been presented through percentile maps in the attempt to express the model outcome through a synthetic indicator (Figs. 2-3). We subsequently calculated the overall mean TIME for each species, defined by averaging the TIME values of all pixels and we grouped 6 classes of percentiles in order to study the temporal deviation of every pixel in respect to the overall mean. Class $0=97.5 \%$ percentile (i.e. $\mu+2 \sigma$ ) represented the "Pessimum" condition (black pixels); Class $1=84.1 \%$ percentile (i.e. $\mu+1 \sigma$ ) represented the "Pejus" condition (pink pixels); Class $2=50 \%$ percentile (i.e. $\mu$ ) represented the "Mean" condition (yellow pixels); Class $3=15 \%$ percentile (i.e. $\mu-1 \sigma$ ) represented the "Good" condition (green pixels); Class $4=2.5 \%$ percentile (i.e. $\mu-2 \sigma$ ) represented the "Optimal" condition (light blue pixels) and Class $5=0.1 \%$ percentile (i.e. $\mu-3 \sigma$ ) represented the "Best" condition (blue pixels) (Figs. 2, 3). In so doing, we classified all pixels and we made all species comparable. This kind of analysis would show, for instance, that if one pixel of a certain target species fall into Class 0 , the environmental conditions supporting growth are the worst and the time to reach the commercial size is the greatest. At the other extreme, if a pixel fall into Class 5 , the time needed to reach the commercial size is the shortest in respect to the mean and so on.

\section{Results}

All DEB models generated outcomes which were in line with already observed data and we are therefore confident that our analysis generated realistic results (see Sarà and Mazzola, 1997; Sarà et al., 1998; Sarà et al., 2018a, 2018b; Sarà et al., 2012 for M. galloprovincialis and C. gigas model validation; Sarà et al., 2018c for D. labrax; Basilone et al., 2006 for Engrauils encrasicolus).

Overall, the increasing temperature from current up to $+2{ }^{\circ} \mathrm{C}$ generated conditions for reducing the time to reach the commercial size in most species of this study. Seabass was the only species that underwent a fluctuating behaviour, in that TIME reduced up to $+1.0^{\circ} \mathrm{C}$ (i.e. 679 days) and later started to increase again reaching 710 days on average in all 68 Sicilian pixels. Bivalves, when not cultivated under IMTA conditions and then separately in respect to fish farms, reduced their TIME of about $4 \%$ and $6 \%$ (Table 2), for Mytilus and Crassostrea, respectively. However, if both bivalves are cultivated under IMTA enriched conditions, as those commonly measured close to the European fish farms, the trophic enrichment generated a sort of synergistic acceleration of TIME of at least 2-3\% more than normo-trophic conditions (no IMTA). While aquaculture species benefited from increasing temperature, to a certain extent, within 10\%, TIME values of the European anchovy decrease to almost $20 \%(17.8 \%$, Table 2$)$ in respect to the current; this translates into a temporal anticipation of reaching the puberty size of almost two months ( 49 days fewer than current). The spatial contextualization of what we observed at single level species follows the same line: the warmer the temperature, the faster the growth. Thus, as shown in Fig. 2, it is easy to observe that when the temperature increases, aquaculture species not cultivated together (Fig. 1), reach the commercial size before current, with some exceptions when temperature was $+1{ }^{\circ} \mathrm{C}$ (black pixels in the northern area). This spatial pattern becomes more robust when species are combined in IMTA, in that the trophic enrichment seems to potentiate the effect of increasing temperature on TIME. Consequently, under a COP21 worst case scenario and under IMTA conditions, many Northern Sicilian pixels change their TIME and all fall into Class 4 and 5 (i.e. the TIME is smaller than 2 and 3 standard deviation units in respect to the mean, meaning that the species grow much faster). In Fig. 3 , the reported maps also combine fishery (Engraulis encrasicolous) pixels. Unfortunately, due to lack of NPP data, we can show only 45 pixels out 68 but this is sufficient for the purpose of this study, as it shows that increasing temperature affects the spatial suitability of most areas around 
Sicily. Specifically, under the worst case COP 21 scenario, only some northern areas will be less suitable for both activities, both with and without IMTA.

\section{Discussion}

Our integrated experimental and modelling approach shows that the increasing temperature within the current thermal species-specific boundaries of present target organisms will cause a general shortening of both cultivation time and length at first maturity (TIME) with an effect which was variable among present target species. The fisheries species will be subjected to a larger reduction, up to two months (about $20 \%$ under the scenario $+2{ }^{\circ} \mathrm{C}$ ) in the time to reach the puberty size, while the effect of increasing temperature on the aquaculture species will be much smaller. While it is not the purpose of this study to comment on the potential adaptive and economic implications induced by our highlighted climate change temporal shifts, we notice that there is a growing body of research showing that climate change induces spatial shifts in terms of distributions towards the poles (Poloczanska et al., 2013), to deeper waters (Dulvy et al., 2008) or following temperature velocity (Pinsky et al., 2013). Also, current literature reports numerous cases of phenological alterations which make species more vulnerable to increasing temperature (Helmuth et al., 2014) and other climate stressors. Our analysis aims to show how a DEB functionalbased approach is able to provide quantities to operationalize the management of some marine activities at local scale. Nevertheless, up to date, DEB has not applied to assess the potential role of phenotypic plasticity in pushing adaptation of species under climate change; this will be a fruitful research ground for DEB scientists, evolutionary biologists and ecologists in the near future. Moreover, we preferred to perform a sensitivity analysis which is more useful than climate projections as those provided by IPCC. While these projections are routinely applied and provide a picture of the potential availability of thermal habitats, they still involve a recognized uncertainty around climate projections and are not able to provide absolute estimates of change in biological traits or range shifts (Payne et al., 2015; Kleisner et al., 2017).

Our modelling outcomes under the current scenario agrees with the common cultivation time for European seabass at these latitudes (about 22-24 months i.e. from 668 to 740 days; FAO CASIP, 2004; FAO, 2014; Sarà et al., 2018c). DEB outcomes for cultured bivalves was in agreement with the reality (e.g. Sarà et al., 2012; FAO, 2014; Martinez et al., 2018) such as that of the European anchovy, whose predicted values fell very well within those reported in the current literature for Sicilian Channel anchovy (Basilone et al., 2006; FAO, 2014).

Our outcomes from the two bivalve aquaculture target species showed that the trophic enrichment due to IMTA potentiates the effects of increasing temperature on TIME in a synergistic combination (sensuGunderson et al., 2016; Sarà et al., 2018a, 2018b, 2018c). A similar effect is not new across the current literature that shows trophic augmented status (i.e. the trophic enrichment due to eutrophication) can work as a buffering factor being able to reduce the detrimental effects of stressor disturbance such as sea acidification (e.g. Connell et al., 2017, 2018). The trophic enrichment due to the IMTA practice produces a comparable effect on our tested aquaculture target species (M. galloprovincialis and C. gigas), although it is not possible to evaluate the economic effects of the further shortening of time to reach the commercial size, it might not necessarily represent a positive outcome.

When the DEB functional-traits outcome is translated at spatial level, by a spatially-contextualised and mapped analysis, it generates easy-to-read maps which are useful to engage with the stakeholders. They can easily identify and proactively implement adaptive site-specific management strategies tailored to target species. By adopting a spatial resolution of $0.11^{\circ}$, which corresponds to 
about $13 \mathrm{~km}$ pixels, we are able to underline some spatial bottlenecks where both fisheries and aquaculture will be not supported by local conditions or where they can be a win-win solution and become successful drivers for local economies. Our analysis allowed to highlight as the Northern Sicilian areas will become unsuitable in the future to both aquaculture activities of $D$. labrax - our target species combined in IMTA - and for the fisheries species, E. encrasicolus; both are weakened by the increasing temperature (e.g. black pixels under current $+1^{\circ} \mathrm{C}$ scenario). Such an analysis can help stakeholders and decision-makers to visualize those areas to be devoted to alternative activities at sea favoring the development of other sectors rather than fisheries and aquaculture, avoiding useless conflicts. On the other hand, designing specific downscaled management measures can be easy at this or higher spatial resolutions. Nonetheless, having seen the difficulty of gathering data at a sufficient scale to feed an adaptive EBM, the objective of oceanographers and climatologists should be that of increasing the resolution of their scenarios to increase the accuracy of the localscale tailored management measures. This should be one of the most important priorities for an adaptive EBM to be able to provide tailored management measures based on ecological functioning principles at a sufficient scale to be realistic in order to reduce future socio-economical conflicts when preserving the ecosystems. The use of mechanistic-derived quantities and high resolution spatial analysis in ecology and resource management science can help us to adopt a medical analogy: the "actual patient care should be highly individualized, and patient treatment should not be based on the results of broad-scale generalizations, without considering the patient's history, risk factors and other medications" (literallyHelmuth et al., 2014). Thus predictions of environmental effects at local scale on biological responses should not be based on only mean conditions of environmental regimes (e.g. monthly, annually), but should rely on higher resolution data (at least daily). A broad-brush approach could be appropriate if high resolution data are lacking, but the present-day technology (e.g. satellite and remote sensing; Capodici et al., 2018) and recent scientific advancement (e.g. DEB theory) offer impressive improvement of the temporal and spatial resolution of many types of data needed to feed regional management strategies. Thanks to DEB, we are now able to incorporate such kind of "patient tailored" information needs to develop appropriate tailored marine resource management.

In conclusion, our final maps can be read as a quantitative informational baseline indicator of climate risk that can be shared and discussed by scientists, policy makers and stakeholders when producing management plans at local level under pressures of climate change. The quantitative mapping of changes in species' thermal habitats and growth performance are an easy-tocommunicate-tool that allows to enlarge the common people's understanding while narrowing the science-policy communication gap and ensuring a more interactive science-policy interface (Kearney and Porter, 2009; Hickey et al., 2013; Shelton, 2014; Pacifici et al., 2015; Payne et al., 2015; Gluckman, 2016; Mangano and Sarà, 2017). Our analysis, focused on a single fishery species and one aquaculture fish, is reductive although our main aim was to show the feasibility of the approach and the effectiveness of the message. Thus, we suggest extending this mechanistic approach to other fishery and aquaculture species, exploiting the power of speciesspecific biological traits (sensu Courchamp et al., 2015). This would help generate predictions about multispecies trade-offs in space and time as well as identify winners and losers in the face of climate change (Sarà et al., 2018c). Freely available multi-species trade-off maps may represent a desirable tool to drive decisionmakers, stakeholders and public opinion in developing adaptation and mitigation solutions at biologically- and ecologically-relevant spatio-temporal scales. Our DEB functional-based approach and the provided scenario-based quantitative maps, showing different simulation outcomes, can represent a tool to analyze and help narrow the field of action to be taken in place (e.g. Decision Support Tools; sensu Punt et al., 2016) and to discuss possible future activities on which to build 
local socio-economies (Mullon et al., 2016; Fernandes et al., 2017). This will allow the fostering of the resilience of the socio-economic environment (i.e. more adaptive, flexible to change) when based on marine resources that respond to rapid changes in a climate change context (Ogier et al., 2016). An adaptive management based on multiple species mechanistic quantities - according to the innovative Ecosystem-Based Fisheries Management (EBFM) - are what European coastal countries need today.

Acknowledgements

Harmony Italy-Malta 2016 grant (n. C1-3.1-31) funded by the Sicilian Region and Maltese Governments supported this research.

Author's contribution

All authors contributed to development of concepts, paper content and data visualization; GS and MCM wrote the manuscript; GS provided funds, hardware and software facilities; all authors reviewed and commented on final manuscript.

\section{References}

Basilone, G., Guisande, C., Patti, B., Mazzola, S., Cuttitta, A., Bonanno, A., Vergara, A., Maneiro, I., 2006. Effect of habitat conditions on reproduction of the European anchovy (Engraulis encrasicolus) in the strait of Sicily. Fish. Oceanogr. 15, 271-280. Baudron, A.R., Fernandes, P.G., 2015. Adverse consequences of stock recovery: European hake, a new "choke" species under a discard ban? Fish Fish. 16, 563-575. Capodici, F., Ciraolo, G., Cosoli, S., Maltese, A., Mangano, M.C., Sarà, G., 2018. Downscaling hydrodynamics features to depict causes of major productivity of Sicilian-Maltese area and implications for resource management. Sci. Total Environ. 628-629, 815-825. Cardoso, J.F.M.F., Witte, J.I.J., Van der Veer, H.W., 2006. Intra- and interspecies comparison of energy flow in bivalve species in Dutch coastal waters by means of the dynamic energy budget (DEB) theory. J. Sea Res. 56, 182-197. Carpenter, S.R., Folke, C., 2006. Ecology for transformation. Trends Ecol. Evol. 21 (6), 309315. Charnov, E.L., Krebs, J.R., 1974. On clutch size and fitness. Ibis 116, 217-219. Cheung, W.W., Jones, M.C., Lam, V.W., Miller, D., Ota, Y., Teh, L., Sumaila, U.R., 2017. Transform high seas management to build climate resilience in marine seafood supply. Fish Fish. 18 (2), 254-263. Claireaux, G., Lagardere, J.P., 1999. Influence of temperature, oxygen and salinity on the metabolism of European sea bass. J. Sea Res. 42, 157-168. Claireaux, G., Lefrançois, C., 2007. Linking environmental variability and fish performance: integration through the concept of scope for activity. Philos Trans R Soc London [Biol] 362 (1487), 2031-2041. Connell, S.D., Doubleday, Z.A., Hamlyn, S.B., Foster, N.R., Harley, C.D.G., Helmuth, B., Kelaher, B.P., Nagelkerken, I., Sarà, G., Russell, B.D., 2017. How ocean acidification can benefit calcifiers. Curr. Biol. 27 (3), R95-R96. Connell, S.D., Doubleday, Z.A., Foster, N.R., Hamlyn, S.B., Harley, C.D.G., Helmuth, B., Kelaher, B.P., Nagelkerken, I., Rodgers, K.L., Sarà, G., Russell, B.D., 2018. The duality of ocean acidification as a resource and a stressor. Ecology 99, 1005-1010. Courchamp, F., Dunne, J.A., Le Maho, Y., May, R.M., Thébaud, C., Hochberg, M.E., 2015. Fundamental ecology is fundamental. Trends Ecol. Evol. 30 (1), 9-16. Cultured Aquatic Species Information Programme (CASIP) 2004. Fishery Fact Sheets Collections. FIGIS Data Collection. In: FAO Fisheries and Aquaculture Department [online]. Rome. Updated 9 December 2004. Cushing, D.H., Humprey, G.H., Banse, K., Laevastui, T., 1958. Report of the committee on terms and equivalents. Rapp P-V Reun Cons Int Explor Mer 144, 15-16. Dalla Via, G.J., Tappeiner, U., Bitterlich, G., 1987. Shore-level related morphological and physiological variations in the mussel Mytilus galloprovincialis (Lamarck, 1819) (Mollusca Bivalvia) in the north Adriatic Sea. Monit Zool Ital 21, 293-305. Dulvy, N.K., Rogers, S.I., Jennings, S., Stelzenm€uller, V., Dye, S.R., Skjoldal, H.R., 2008. 
Climate change and deepening of the North Sea fish assemblage: a biotic indicator of warming seas. J. Appl. Ecol. 45, 1029-1039. Eroldoğan, O.T., Kumlu, M., Aktaş, M., 2004. Optimum feeding rates for European sea bass Dicentrarchus labrax L. reared in seawater and freshwater. Aquaculture 231 (1), 501-515. FAO, IFAD and WFP, 2014. The State of Food Insecurity in the World 2014. In: M.C. Mangano et al. Journal of Sea Research $x x x(x x x x) x x x-x x x 7$ Strengthening the Enabling Environment for Food Security and Nutrition, Rome, FAO. Fernandes, J.A., Papathanasopoulou, E., Hattam, C., Queirós, A.M., Cheung, W.W., Yool, A., Calosi, P., 2017. Estimating the ecological, economic and social impacts of ocean acidification and warming on UK fisheries. Fish Fish. 18 (3), 389-411. Freitas, V., Cardoso, J.F., Lika, K., Peck, M.A., Campos, J., Kooijman, S.A., Van der Veer, H.W., 2010. Temperature tolerance and energetics: a dynamic energy budget-based comparison of North Atlantic marine species. Philos. Trans. R. Soc. Lond. Ser. B Biol. Sci. 365 (1557), 3553-3565. Gluckman, P., 2016. The science-policy interface. Science 353 (6303), 969. http://dx.doi. org/10.1126/science.aai8837. Gunderson, A.R., Armstrong, E.J., Stillman, J.H., 2016. Multiple stressors in a changing world: the need for an improved perspective on physiological responses to the dynamic marine environment. Annu. Rev. Mar. Sci. 8, 357-378. Helmuth, B., Russell, B.D., Connell, S.D., Dong, Y., Harley, C.D., Lima, F.P., Sarà, G., Mieszkowska, N., 2014. Beyond long-term averages: making biological sense of a rapidly changing world. Clim Change Resp 1 (1), 6. Hickey, G.M., Forest, P., Sandall, J.L., Lalor, B.M., Keenan, R.J., 2013. Managing the environmental sciencepolicy nexus in government: perspectives from public servants in Canada and Australia. Sci. Public Policy 40 (4), 529-543. Holling, C.S., 1959. The components of predation as revealed by a study of small mammal predation of the European pine sawfly. Can. Entomol. 91, 293-320. Hulme, M., 2016a. $1.5^{\circ} \mathrm{C}$ and climate research after the Paris agreement. Nat. Clim. Chang. 6 (3), 222-224. Hulme, M., 2016b. $1.5 \mathrm{C}$ and climate research after the Paris agreement. Nat. Clim. Chang. 6 (3), 222. Kearney, M., 2012. Metabolic theory, life history and the distribution of a terrestrial ectotherm. Funct. Ecol. 26 (1), 167-179. Kearney, M.R., Porter, W., 2009. Mechanistic niche modelling: combining physiological and spatial data to predict species' ranges. Ecol. Lett. 12 (4), 334-350. Kearney, M.R., Domingos, T., Nisbet, R., 2015. Dynamic energy budget theory: an efficient and general theory for ecology. Bioscience 65 (4), 341. Kleisner, K.M., Fogarty, M.J., McGee, S., Hare, J.A., Moret, S., Peretti, C.T., Saba, V.S., 2017. Marine species distribution shifts on the U.S. north east continental shelf under continued ocean warming. Prog. Oceanogr. 153, 24-36. Kooijman, S.A.L.M., 2010. Dynamic Energy Budget Theory for Metabolic Organisation, third ed. Cambridge University Press, Cambridge, U.K. Lam, V.W.Y., Cheung, W.W.L., Sumaila, U.R., 2016. Marine capture fisheries in the Arctic: winners or losers under climate change and ocean acidification? Fish Fish. 17, 335-357. Loreau, M., 2010. From Populations to Ecosystems: Theoretical Foundations for a New Ecological Synthesis. Princeton University Press, Princeton (328 pp). Mangano, M.C., Sarà, G., 2017. Collating science-based evidence to inform public opinion on the environmental effects of marine drilling platforms in the Mediterranean Sea. J. Environ. Manag. 188, 195-202. Mangano, M.C., Bottari, T., Caridi, F., Porporato, E.M.D., Rinelli, P., Spanò, N., Johnson, M., Sarà, G., 2017a. The effectiveness of fish feeding behaviour in mirroring trawlinginduced patterns. Mar. Environ. Res. 131, 195-204. Mangano, M.C., Kaiser, M.J., Porporato, E.M.D., Lambert, G.I., Spanò, N., 2017b. Trawling disturbance effects on the trophic ecology of two co-generic Astropectinid species. Mediterr. Mar. Sci. 16 (3), 538-549. Marquet, P.A., Allen, A.P., Brown, J.H., Dunne, J.A., Enquist, B.J., Gillooly, J.F., Gowaty, P.A., Green, J.L., Harte, J., Hubbel, S.P., O'dwyer, J., Okie, J.G., Ostling, A., Ritchie, M., Stork, D., West, G.B., 2014. On theory in ecology. Bioscience 64 (8), 701-710. Martinez, M., Mangano, M.C., Maricchiolo, G., Genovese, L., Mazzola, A., Sarà, G., 2018. Measuring the effects of temperature rise on Mediterranean shellfish aquaculture. Ecol. Indic. 88, 71-78. Mieszkowska, N., Sugden, H., Firth, L.B., Hawkins, S.J., 2014. The role of sustained observations in tracking impacts of environmental change on marine biodiversity and ecosystems. Phil. Trans. R. Soc. A 372 (2025), 
20130339. Montalto, V., Sarà, G., Ruti, P.M., Dell'Aquila, A., Helmuth, B., 2014. Testing the effects of temporal data resolution on predictions of the effects of climate change on bivalves. Ecol. Model.

278, 1-8. Montalto, V., Helmuth, B., Ruti, P.M., Dell'Aquila, A., Rinaldi, A., Sarà, G., 2016. Mechanistic approach reveals unexpected consequences of climate change on mussels throughout the Mediterranean Sea. Clim. Chang. 139, 293-306. Moss, R.H., Edmonds, J.A., Hibbard, K.A., Manning, M.R., Rose, S.K., Van Vuuren, D.P., Carter, T.R., Emori, S., Kainuma, M., Kram, T., Meehl, G.A., Mitchell, J.F.B., Nakicenovic, N., Riahi, K., Smith, S.J., Stouffer, R.J., Thomson, A.M., Weyant, J.P., Wilbanks, T.J., 2010. The next generation of scenarios for climate change research and assessment. Nature 463, 747-756. Mullon, C., Steinmetz, F., Merino, G., Fernandes, J.A., Cheung, W.W.L., Butenschön, M., Barange, M., 2016. Quantitative pathways for north East Atlantic fisheries based on climate, ecological-economic and governance modelling scenarios. Ecol. Model. 320, 273-291. Ogier, E.M., Davidson, J., Fidelman, P., Haward, M., Hobday, A.J., Holbrook, N.J., Hoshino, E., Pecl, G.T., 2016. Fisheries management approaches as platforms for climate change adaptation: comparing theory and practice in Australian fisheries. Mar. Policy 71, 82-93. Pacifici, M., Foden, W.B., Visconti, P., Watson, J.E., Butchart, S.H., Kovacs, K.M., Scheffers, B.R., Hole, D.G., Martin, T.G., Akçakaya, H.R., Corlett, R.T., Huntley, B., Bickford, D., Carr, J.A., Hoffmann, A.A., Midgley, G.F., Pearce-Kelly, P., Pearson, R.G., Williams, S.E., Willis, S.G., Young, B., Rondinini, C., 2015. Assessing species vulnerability to climate change. Nat. Clim. Chang. 5 (3), 215. Payne, M.R., Barange, M., Cheung, W.W., MacKenzie, B.R., Batchelder, H.P., Cormon, X., Eddy, T.D., Fernandes, J.A., Hollowed, A.B., Jones, M.C., Link, J.S., Neubauer, P., Ortiz, I., Queirós, A.M., Paula, J.R., 2015. Uncertainties in projecting climate-change impacts in marine ecosystems. ICES J. Mar. Sci. 73 (5), 1272-1282. Pecl, G.T., et al., 2017. Biodiversity redistribution under climate change: impacts on ecosystems and human well-being. Science 355 (6332), eaai9214. Person-Le Ruyet, J., Mahé, K., Le Bayon, N., Le Delliou, H., 2004. Effects of temperature on growth and metabolism in a Mediterranean population of European sea bass, Dicentrarchus labrax. Aquaculture 237, 269-280. Pethybridge, H., Roos, D., Loizeau, V., Pecquerie, L., Bacher, C., 2013. Responses of European anchovy vital rates and population growth to environmental fluctuations: an individual-based modelling approach. Ecol. Model. 250, 370-383. Pinsky, M.L., Worm, B., Fogarty, M.J., Sarmiento, J.L., Levin, S.A., 2013. Marine taxa track local climate velocities. Science 341, 1239-1242. Poloczanska, E.S., Brown, C.J., Sydeman, W.J., Kiessling, W., Schoeman, D.S., Moore, P.J., Brander, K., Bruno, J.F., Buckley, L.B., Burrows, M.T., Duarte, C.M., Halpern, B.S., Holding, J., Kappel, C.V., O'Connor, M.I., Pandolfi, J.M., Parmesan, C., Schwing, F., Thompson, S.A., Richardson, A.J., 2013. Global imprint of climate change on marine life. Nat. Clim. Chang. 3, 919-925. Pouvreau, S., Bourles, Y., Lefebvre, S., Gangnery, A., Alunno-Bruscia, M., 2006. Application of a dynamic energy budget model to the Pacific oyster, Crassostrea gigas, reared under various environmental conditions. J. Sea Res. 56, 156-167. Punt, A.E., Butterworth, D.S., Moor, C.L., De Oliveira, J.A., Haddon, M., 2016. Management strategy evaluation: best practices. Fish Fish. 17 (2), 303-334. Rico-Villa, B., Bernard, I., Robert, R., Pouvreau, S., 2010. A dynamic energy budget (DEB) growth model for Pacific oyster larvae, Crassostrea gigas. Aquaculture 305, 84-94. Rutterford, L.A., Simpson, S.D., Jennings, S., Johnson, M.P., Blanchard, J.L., Schön, P.J., Sims, D.W., Tinker, J., Genner, M.J., 2015. Future fish distributions constrained by depth in warming seas. Nat. Clim. Chang. 5 (6), 569. Sarà, G., Mazzola, A., 1997. Effects of trophic and environmental conditions on the growth of Crassostrea gigas in culture. Aquaculture 153, 81-91. Sarà, G., Manganaro, A., Cortese, G., Pusceddu, A., Mazzola, A., 1998. The relationship between food availability and growth of Mytilus galloprovincialis (LMK, 1819) in the open-sea (South Mediterranean). Aquaculture 167, 1-15. Sarà, G., Kearney, M., Helmuth, B., 2011. Combining heattransfer and energy budget models to predict local and geographic patterns of mortality in Mediterranean intertidal mussels. Chem. Ecol. 27, 135-145. Sarà, G., Reid, G., Rinaldi, A., Palmeri, V., Troell, M., Kooijman, S.A.L.M., 2012. Growth and reproductive simulation of candidate shellfish 
species at fish cages in the southern Mediterranean: dynamic energy budget (DEB) modelling for integrated multi-trophic aquaculture. Aquaculture 324, 259-266. Sarà, G., Palmeri, V., Montalto, V., Rinaldi, A., Widdows, J., 2013a. Parameterisation of bivalve functional traits for mechanistic ecophysiological dynamic energy budget (DEB) models. Mar. Ecol. Prog. Ser. 480, 99-117. Sarà, G., Palmeri, V., Rinaldi, A., Montalto, V., Helmuth, B., 2013b. Predicting biological invasions in marine habitats through eco-physiological mechanistic models: a study case with the bivalve Brachidontes pharaonis. Divers. Distrib. 19, 1235-1247. Sarà, G., Rinaldi, A., Montalto, V., 2014. Thinking beyond organism energy use: a trait based bioenergetic mechanistic approach for predictions of life history traits in marine organisms. Mar. Ecol. 35, 506-515. Sarà, G., Mangano, M.C., Johnson, M., Mazzola, A., 2018a. Integrating multiple stressors in aquaculture to build the blue growth in a changing sea. Hydrobiologia 809, 5. http://dx.doi.org/10.1007/s10750-017-3469-8. Sarà, G., Porporato, E.M.D., Mangano, M.C., Mieszkowska, N., 2018b. Multiple stressors facilitate the spread of a non-indigenous bivalve in the Mediterranean Sea. J. Biogeogr. 45 (5), 1090-1103. Sarà, G., Gouhier, T.C., Brigolin, D., Porporato, E.M., Mangano, M.C., Mirto, S., Mazzola, A., Pastres, R., 2018c. Predicting shifting sustainability tradeoffs in marine finfish aquaculture under climate change. Glob. Chang. Biol Accepted Author Manuscript. https://doi.org/10.1111/gcb.14296. Schneider, K.R., 2008. Heat stress in the intertidal: comparing survival and growth of an invasive and native mussel under a variety of thermal conditions. Biol. Bull. 215, 253-264. Schoener, T.W., 1989. Mechanistic approaches to community ecology: a new reductionism. Am. Zool. 26, 81-106. Shelton, C., 2014. FAO Fisheries and Aquaculture Circular No. 1088. Rome, FAO. Vol. 34. Strömberg, K.H.P., Smyth, T.J., Allen, J.I., Pitois, S., O'Brien, T.D., 2009. Estimation of global zooplankton biomass from satellite ocean colour. J. Mar. Syst. 78, 18-27. Teal, L.R., Hal, R., Kooten, T., Ruardij, P., Rijnsdorp, A.D., 2012. Bio-energetics underpins the spatial response of North Sea plaice (Pleuronectes platessa L.) and sole (Solea solea L.) to climate change. Glob. Chang. Biol. 18 (11), 3291-3305. Thomas, Y., Mazurié, J., Pouvreau, S., Bacher, C., Gohin, F., Struski, C., Le Mao, P., 2006. Modélisation de la croissance de la moule Mytilus edulis (L.), en fonction des pratiques culturales et de données environnementales. In: Application aux résultats de 2003-2004 en baie du. Mont Saint-Michel. Rapport d'avancement de contrat N05/2 210 106/F. IFREMER, Laboratoire Environnement Ressource Morbihan Pays de Loire, 12 rue des résistants, BP86 56740 La Trinité/mer, France. UNEP/MAP, 2016. Mediterranean Strategy for Sustainable Development. 2016-2025. Plan Bleu, Regional Activity Centre, Valbonne. van der Meer, J., 2006. An introduction to dynamic energy budget (DEB) models with special emphasis on parameter estimation. J. Sea Res. 56, 85-102. 


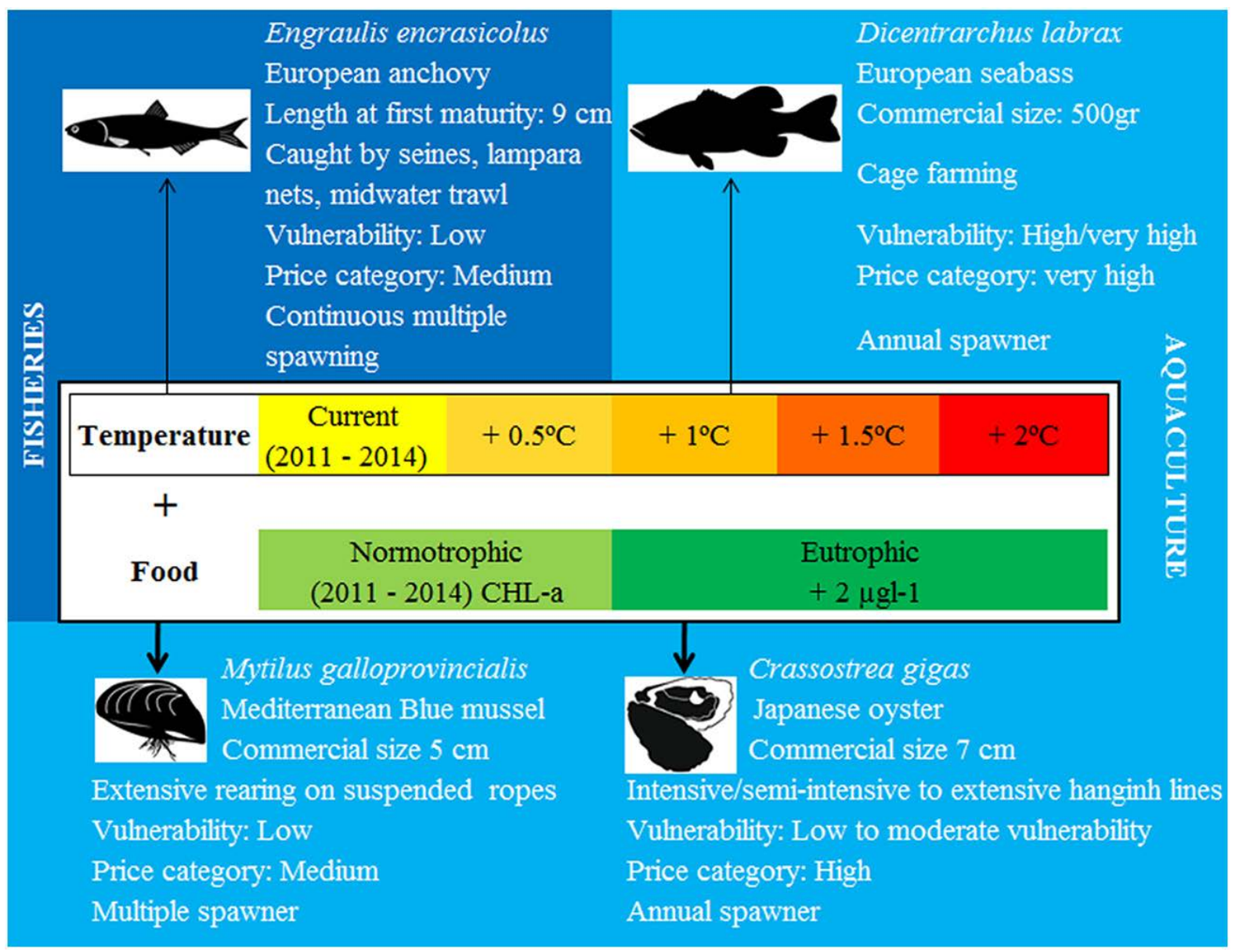

Fig. 1. Conceptual framework showing the simulated scenario of "temperature" increase (from current scenarios, years 2011-2014 to $+2{ }^{\circ} \mathrm{C}$, step $0.5^{\circ} \mathrm{C}$ ) and "food" increase (from a current "normotrophic" condition, 2011-2014 CHL-a, to

"eutrophic" condition $+2 \mu \mathrm{gl}-1$ ). Variation of the commercial

size, proxy of the duration of the grow-out production

phase, have been modelled along a temperature and food increasing scenarios for the two bivalve aquaculture target species (Mytilus galloprovincialis and Crassostrea gigas) in order to text the Integrated Multi-Trophic Aquaculture, IMTA, effects as a potential management solution in a context of an adaptive ecosystem based approach. Variations of the commercial size of the farmed fish, Dicentrarchus labrax, and

length at first maturity on the fisheries target species,

Engraulis encrasicolus, have been modelled along a temperatureincreasing scenario only. Notes: the $+2{ }^{\circ} \mathrm{C}$ temperature increase value reflects the foreseen worst temperature increasing scenario in COP21 (Paris climate conference

Agreement, 2015); the +2 ugl- 1 food increase value

(Chlorophyll-a, CHL-a) reflects an eutrophic condition simulating the trophic enrichment of a typical IMTA, condition.

Data on the farming or fisheries methods, selected sizes,

vulnerability, price and spawning have been reported to better characterise the selected target species (FAO CASIP, 2004http://www.fao.org/fishery/culturedspecies; https:// www.fishbase.org/; http://www.sealifebase.org/). 
Table 1

DEB parameters for Mytilus galloprovincialis, Crasssostrea gigas, Dicentrarchus labrax and Engraulis encrasicolus (1 = Kooijman, 2010, 2 = van der Meer, 2006, 3 = Sarà et al., 2011, $4=$ Thomas et al., 2006; $5=$ Schneider, 2008; $6=$ Rico-Villa et al., 2010; $7=$ Cardoso et al., 2006; 8 = Pouvreau et al., 2006; 9 = Sarà et al., 2018c; $10=$ Freitas et al., 2010; 11 = Eroldoğan et al., 2004; 12 = Dalla Via et al., 1987; Claireaux and Lagardere, 1999; Person-Le Ruyet et al., 2004; Claireaux and Lefrançois, 2007; 13 = Pethybridge et al., 2013; $14=$ Teal et al., 2012); ${ }^{*}$ denotes parameters governing physiological rates based on experimental data at $25^{\circ} \mathrm{C}$, the others are given at the respective reference temperature.

Symbol Description Units Mytilus galloprovincialis Crassostrea gigas Dicentrarchus labrax Engraulis encrasicolus

Value Ref Value Ref Value Ref Value Ref Vb Structural volume at birth

$\mathrm{cm}^{3} 0.000001310 .000000156 ; 7--0.00022513$

Vs Structural volume at seeding $\mathrm{cm}^{3}----4.179--$

Vp Structural volume at puberty $\mathrm{cm}^{3} 0.0621 .407419 .60101 .7313$

$\delta_{\mathrm{M}}$ Shape coefficient $-0.225-0.175-0.217100 .169-$

$\left\{J_{\text {ณ̆ }\}}\right.$

Maximum surface area-specific ingestion rate $\mathrm{J} \mathrm{cm}^{-2}$

$8.2423 .37^{*} 58.5913 .513$

ae Assimilation efficiency -0.8830 .7580 .89110 .7113$

$\mathrm{X}_{\mathrm{K}} \quad$ Saturation

$\mu \mathrm{g} \mathrm{I}^{-1} \quad 2.1$

3

9.5

8

0.034

9

[E $\mathrm{E}_{\mathrm{G}}$ ] Volume-specific cost of growth $\mathrm{J} \mathrm{cm}^{3} 5993519006560010400013$

$\left[E_{\mathrm{m}}\right]$ Maximum storage density J cm ${ }^{3} 2190222956385010270013$

[ $\left.\dot{p}_{\mathrm{M}}\right] \quad$ Volume-specific maintenance cost $\mathrm{J} \mathrm{cm}^{-3} \mathrm{~h}^{-1} \quad 1$ 13

K Fraction of utilized energy spent on maintenance and growth

$K_{R} \quad$ Reproduction efficiency

$\mathrm{T}_{\mathrm{A}} \quad$ Arrhenius temperature

$\mathrm{T}_{\mathrm{L}} \quad$ Lower boundary of tolerance range

$\mathrm{T}_{\mathrm{H}} \quad$ Upper boundary of tolerance range

$\mathrm{T}_{\mathrm{AL}} \quad$ Rate of decrease at lower boundary

$\mathrm{T}_{\mathrm{AH}} \quad$ Rate of decrease at upper boundary

$\begin{array}{ll}\mathrm{J} \mathrm{cm}^{-3} \mathrm{~h}^{-1} & 1 \\ - & 0.7 \\ - & 0.8 \\ { }^{\circ} \mathrm{K} & 7022 \\ { }^{\circ} \mathrm{K} & 275 \\ { }^{\circ} \mathrm{K} & 296 \\ { }^{\circ} \mathrm{K} & 45430 \\ { }^{\circ} \mathrm{K} & 31376\end{array}$

2

24

0.8

0.7

5800

281

305

75000

30000
6*

1.71

free fit $\quad 0.8$

9

$8 \quad 0.95$

$-\quad 6228$

279

303

7333

3961
0.7

0.95

9800

278

305

50000

100000
13

13

14

14

14 

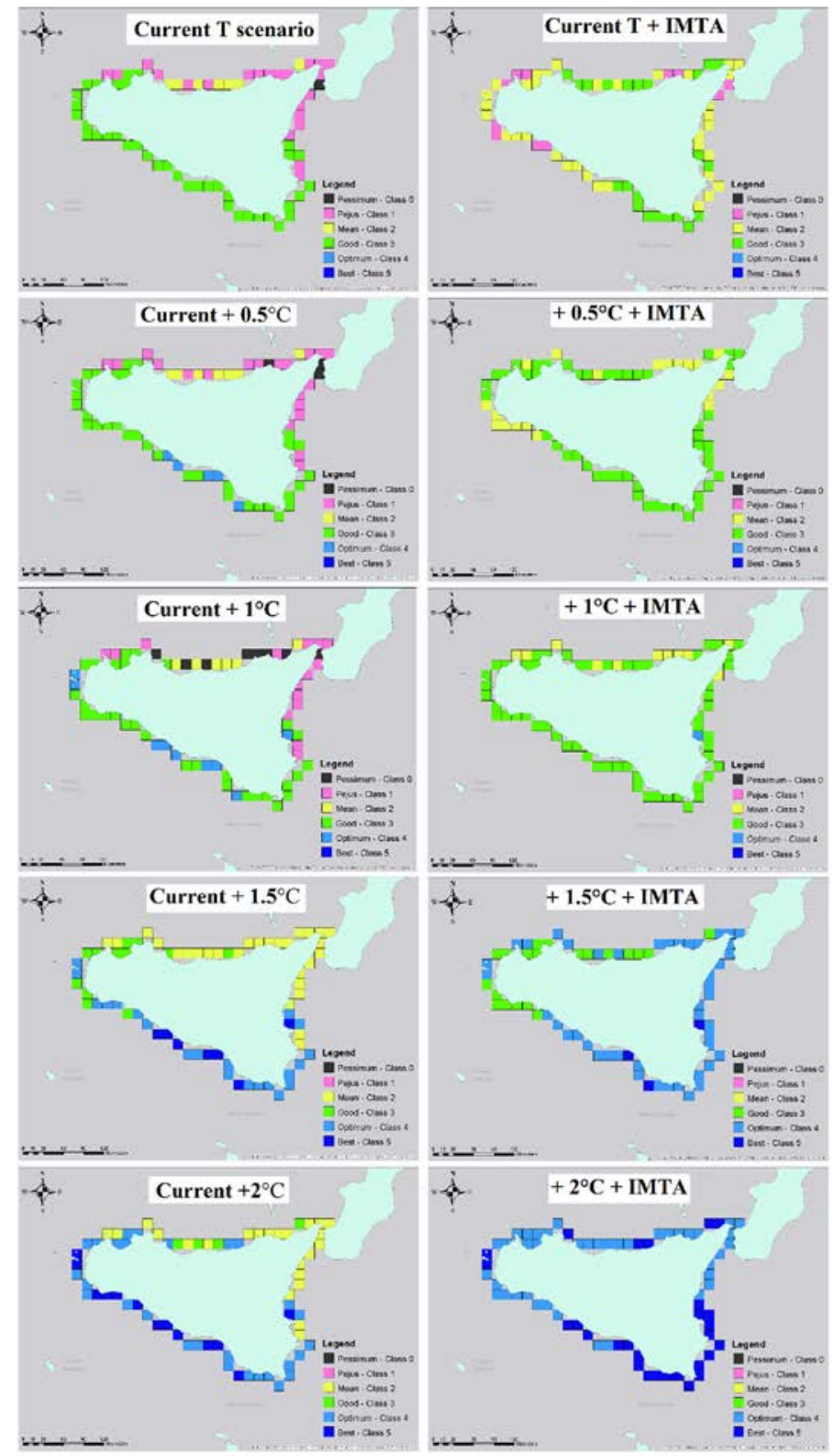

Fig. 2. Aquaculture target species - D. labrax, C. gigas and $\mathrm{M}$. galloprovincialis - maps showing the percentile class in which each pixel around Sicily falls. On the left panel of each rows the mapped outcome obtained by cultivating species separately; on the right panel the mapped outcome obtained when species were combined in IMTA. From top to bottom mapped outcome under increasing temperature conditions from current up to current $+2{ }^{\circ} \mathrm{C}$

(step $0.5^{\circ} \mathrm{C}$; the first panel of each column is the

current, the last panel current $+2{ }^{\circ} \mathrm{C}$ ).

Black="Pessimum" condition (Class 0, 97.5\% percentile,

i.e. $\mu+2 \sigma$ ); Pink="Pejus" condition (Class

$1,84.1 \%$ percentile, i.e. $\mu+1 \sigma$ ); Yellow="Mean"

condition (Class $2,50 \%$ percentile, i.e. $\mu$ );

Green="Good" condition (Class 3, 15\% percentile,

i.e. $\mu-1 \sigma$ ); Light blue="Optimal" condition (Class 4 ,

$2.5 \%$ percentile, i.e. $\mu-2 \sigma$ ); Blue="Best" condition

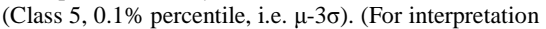

of the references to colour in this figure legend,

the reader is referred to the web version of this article.) 


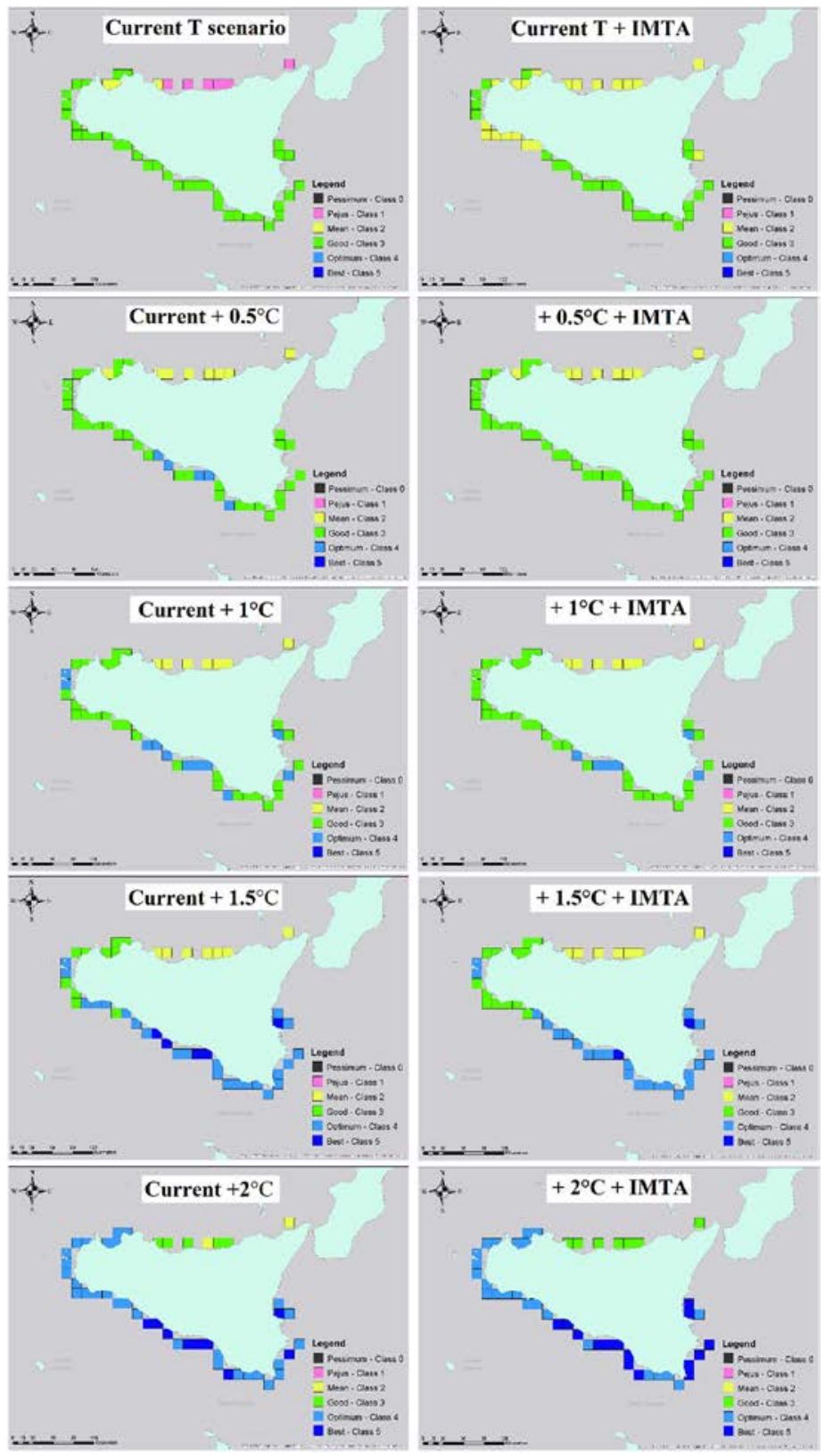

Fig. 3. Maps showing the percentile class in which each pixel around Sicily falls when combining fishery and aquaculture target species. On the left panel of each rows the mapped outcome obtained by cultivating species separately; on the right panel the mapped outcome obtained when species were combined in IMTA. From top to bottom mapped outcome under increasing temperature conditions from current up to current $+2{ }^{\circ} \mathrm{C}$ (step $0.5^{\circ} \mathrm{C}$; the first panel of each column is the current, the last panel current $+2{ }^{\circ} \mathrm{C}$ ). Black="Pessimum" condition (Class 0 , 97.5\% percentile, i.e. $\mu+2 \sigma$ ); Pink="Pejus" condition (Class 1, 84.1\% percentile, i.e. $\mu+1 \sigma$ );

Yellow="Mean" condition (Class 2, 50\% percentile, i.e. $\mu$ ); Green="Good" condition (Class 3, 15\% percentile, i.e. $\mu-1 \sigma)$; Light blue="Optimal" condition (Class $4,2.5 \%$ percentile, i.e. $\mu-2 \sigma$ );

Blue="Best" condition (Class 5, 0.1\% percentile,

i.e. $\mu-3 \sigma$ ). (For interpretation of the references to colour in this figure legend, the reader is referred to the web version of this article.) 
Table 2

a) The estimated time to reach the commercial size (TIME) for the whole study area in all scenarios and $b$ ) the percentage difference between TIME under current conditions and other scenarios.

\begin{tabular}{|c|c|c|c|c|c|}
\hline a) TIME & Current & $\begin{array}{l}\text { Current } \\
+0.5^{\circ}\end{array}$ & $\begin{array}{l}\text { Current } \\
+1.0^{\circ}\end{array}$ & $\begin{array}{l}\text { Current } \\
+1.5^{\circ}\end{array}$ & $\begin{array}{l}\text { Current } \\
+2.0^{\circ}\end{array}$ \\
\hline $\begin{array}{l}\text { Engraulis } \\
\quad \text { encrasicolous }\end{array}$ & 273 & 260 & 247 & 235 & 224 \\
\hline Dicentrarchus labrax & 700 & 685 & 679 & 685 & 710 \\
\hline $\begin{array}{l}\text { Mytilus } \\
\quad \text { galloprovincialis }\end{array}$ & 967 & 957 & 947 & 938 & 929 \\
\hline Crassostrea gigas & 1135 & 1114 & 1098 & 1082 & 1068 \\
\hline $\begin{array}{l}\text { M. galloprovincialis } \\
\text { IMTA }\end{array}$ & 538 & 529 & 519 & 509 & 498 \\
\hline C. gigas IMTA & 205 & 201 & 197 & 193 & 188 \\
\hline b) TIME Diff $\%$ & Current & $\begin{array}{l}\text { Current } \\
+0.5^{\circ}\end{array}$ & $\begin{array}{l}\text { Current } \\
+1.0^{\circ}\end{array}$ & $\begin{array}{l}\text { Current } \\
+1.5^{\circ}\end{array}$ & $\begin{array}{l}\text { Current } \\
+2.0^{\circ}\end{array}$ \\
\hline $\begin{array}{l}\text { Engraulis } \\
\quad \text { encrasicolous }\end{array}$ & - & 4.7 & 9.3 & 13.7 & 17.8 \\
\hline Dicentrarchus labrax & - & 2.2 & 3.0 & 2.2 & -1.4 \\
\hline $\begin{array}{l}\text { Mytilus } \\
\quad \text { galloprovincialis }\end{array}$ & - & 1.1 & 2.1 & 3.0 & 3.9 \\
\hline Crassostrea gigas & -1.9 & & 3.3 & 4.7 & 5.9 \\
\hline $\begin{array}{l}\text { M. galloprovincialis } \\
\text { IMTA }\end{array}$ & -1.8 & & 3.6 & 5.5 & 7.4 \\
\hline C. gigas IMTA & -2.1 & & 4.1 & 6.1 & 8.2 \\
\hline
\end{tabular}

